\title{
系統交通信号におけるサイクル制御の研究 \\ CYCLE TIME CONTROL FOR COORDINATED TRAFFIC SIGNALS
}

\begin{tabular}{lll} 
越 & \multicolumn{2}{c}{ 正 毅* $^{\text {By }}$ Masaki KOSHI }
\end{tabular}

\section{1.はじめに}

系統制御される交通信号群に対しては, 一般に共通の サイクルが用いられる。したがって，個々の信号やリン クにとっては，必ずしも最適サイクルとはならず，系統 全体としてのサイクル最適化問題となるのであるが, 在 来の研究においては, このサイクルの問題にはあまり十 分な注意が払われたことはなく，また実際の広域交通制 御においても, かなり安易にサイクルが決められてき た。

この研究は，モデルによる理論と実験結果とに基づい て, 系統制御サイクルと遅れおよび停止との関係を明ら かにし, 車両と歩行者との双方についての最適系統サイ クルについて検討したものである。

まず，単純化したモデル計算によって，系統制御され る交差点における車両交通の遅れ, および停止台数と贲 イクルとの関係を示し, 最適サイクルが孤立交差点の場 合とは明らかに異なることを示した。

小規模実験システムを用いた実験值に基づいて，上の 単純化モデルによる結果を検証し, 最適系統サイクルが 走行速度と信号間隔とに依存して決まること, 遅れおよ び停止がサイクルによって，かなり大幅に変化するもの であることを示した。

次にサイクルのオンライン自動制御のひとつの方法と して, 遅れあるいは停止台数のサイクルに関する微係数 をオンライン計測し, これに基づいてサイクルのフィー ドバック制御を行う方法を提示し，小規模実験システム における実験結果を示した。その結果, この制御方法が 理論どおりの動作を示すが，そのために局地最適サイク ルに陥ち込んでしまうために，実用にあたっては注意が 必要であることが知られた。

現実の都市内街路網の密な信号間隔と低い走行速度の

\footnotetext{
* 正会員 工博 東京大学助教授 生産技術研究所
}

もとにおいては, サイクルと車両の遅れとはほぼ比例関 倸にあることが多く, また, 歩行者の横断遅れも, 通常 のサイクルの範囲ではサイクルの増加とともに増加する 関係にある。したがって，80 120 sec 程度の常用のサ イクルの範冊内では，できるだけ短いサイクルを用いる という単純な政策が実用的には有効であるということが できる。

\section{2. 簡単なモデルによる計算}

\section{（1）孤立した交差点}

孤立した単独交差点における遅れとサイクルとの関係 については, Webster ${ }^{1)}$ らの研究によって, 図一1のよ うに表わされることが知られている。ひとつの停止線に おける平均遅れは, 最適サイクル $C_{\mathrm{op}}$ をこえた領域で はサイクルの増加とともに増す傾向にある。C $\mathrm{op}$ はポア ソン到着の場合には, 容量上の条件から決まる最小サイ クル $C_{\min }$ の約 2 倍程度となるのが普通である ${ }^{1), 2)}$ 。一 様到着流を持つ過飽和でない停止線における遅れと停止 とを考えてみる。

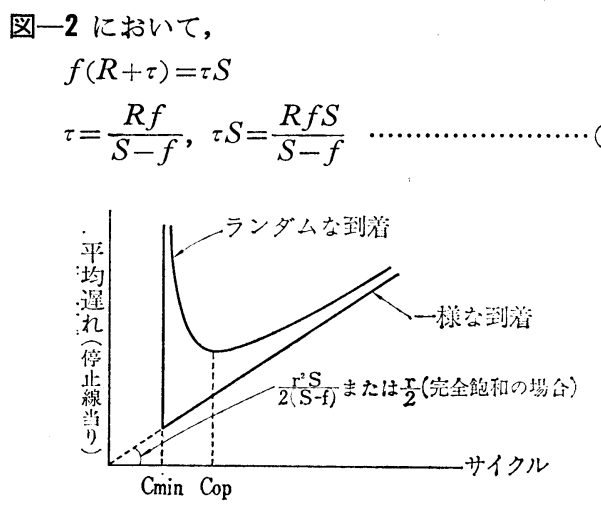

図一1孤立した単独交差点における遅れと サイクルとの関係 


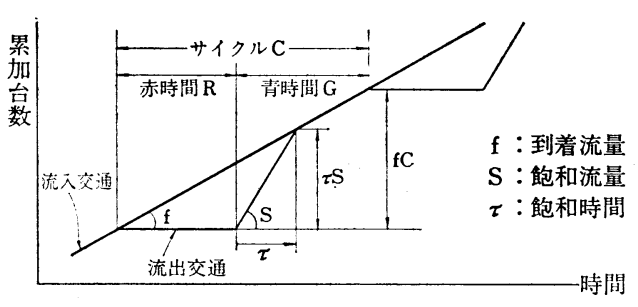

図-2 一様到围の場合の停止台数

ここに,

$f:$ 到着流量 (台/sec)

$S:$ 飽和流量 $($ 台 $/ \mathrm{sec})$

? : 飽和時間 (1 回の青表示のうち, 飽和してい る時間) (sec)

$G:$ 青時間 $(\mathrm{sec})$

$R:$ 赤時間 $(\mathrm{sec})$

$C:$ サイク $(\mathrm{sec})$

過飽和でないといら前提からして, $\leqq G$ である。 1 サイクル当り遅れ $D$ は

$$
D=\frac{1}{2} R \cdot \tau S=\frac{1}{2} \cdot \frac{R^{2} f S}{S-f}
$$

平均遅れ $d$ は

$$
\begin{aligned}
& \quad d=\frac{D}{f C}=\frac{1}{2 C} \cdot \frac{R^{2} S}{S-f}=\frac{r^{2} S}{2(S-f)} \cdot C \\
& \text { ここに, } \\
& \quad r=\frac{R}{C}
\end{aligned}
$$

となるので, 図一1 における漸近線の勾配は $r^{2} S / 2(S-$ $f)$ となる。もし完全に飽和していれば，平均待ち時間 は図一2 から $R / 2$ となる。

同様に, 一様到着流の場合の平均停止回数 $\tau \cdot S / f \cdot C$ を求めて見ると, 式 (1) から,

$$
\frac{\tau S}{f C}=\frac{S}{f C} \cdot \frac{R f}{S-f}=\frac{S}{S-f} \cdot \frac{R}{C}
$$

となる。いま, 1 サイクル当り損失時間を $L$ とし, 有 効青の和 $C-L$ の一定割合 $g(C-L)$ が青時間 $G$ とし て与えられると仮定すると，

$$
R=C-G=C-g(C-L)=C(1-g)+g L
$$

$$
\text { ここに, }
$$

$$
\begin{aligned}
& L: 1 \text { サイクル当り損失時間 } \\
& g: G / C
\end{aligned}
$$

となり，これを式（2）に代入して，

平均停止回数 $=\frac{S}{S-f} \cdot\left\{(1-g)-\frac{g L}{C}\right\}$

が得られる。 $C_{\min }$ は $\tau S=f C$, すなわち平均停止回数 $=1$ となるサイクルである。ランダムな到着の場合に は, $C_{\min }$ では平衡行列長は 無限となるであろう。これ らから, 平均停止回数とサイクルとの関係は, 図一3の ようになるであろう。

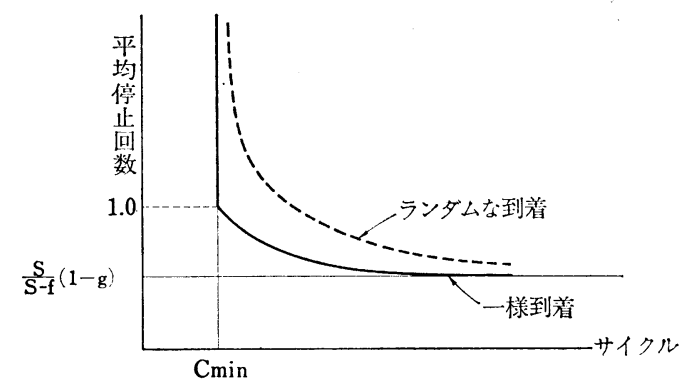

図一3 孤立した交差点における平均停止回数と サイクルとの関係

\section{（2）系統制御される交差点}

系統制御される場合には, 到着交通が一様でもランダ ムでもなく, 周期性を持っている。特殊な場合を除いて は，到着分布の周期はサイクルに等しい。

枝村ら ${ }^{3}$ は, 車群の㧨散を考慮した一般的な単一方形 波モデルによって, 単数および複数リンクの系統サイク ルと, 遅れとの関係を計算例によって示したが, ここで はこの関係をさらに

一般化するために, もっとも単純な単一 飽和方形波モデルに よって遅れおよび停 止とサイクルとの関 係を考えて見る。

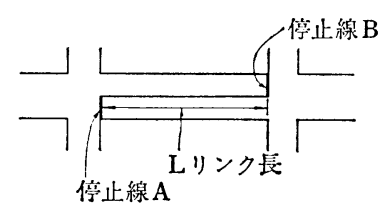

図一4 系統制御される単純なリンク

もっとも単純なモデルとして, 図一4のような系統制 御される隣り合った $2 つ の$ 信号交差点にはさまれたリン クについて，次の仮定のもとに考えてみよう。

仮定

1. リンク両端の信号のサイクル・スプリット・飽和 流量は等しい。

2. 直進交通のみであり, 速度は一定で車群の拡散は ない。

3. スプリットは系統方向に対して青 50\%，赤 50\% であり，完全に飽和している。

上の仮定から，両信号への到着交通波形は図一5 のよ うな単一飽和方形波となる。

図一6 から，サイクル $C$ がリンクの往復所要時間 $T$ の整数分の 1 であれば通過帯のせばまりはなく, 遅れは 0である。

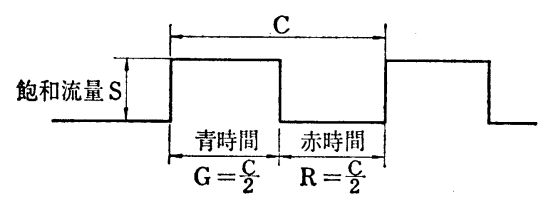

図一5 単一飽和方形波到萺モデル 


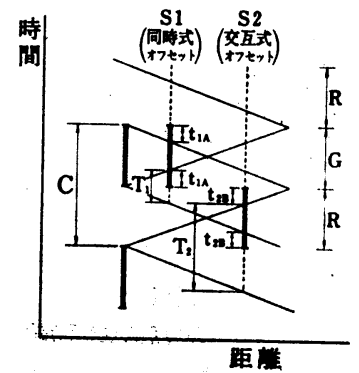

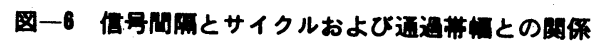
一般に

$$
t=\operatorname{Min}|n \cdot C-T|
$$
$こ こ に$,
$T:$ リンク往復所要時間
$C:$ サイル

$n:$ 整数 $0,1,2, \cdots \cdots$

とすると, $t$ は通過帯のせばまり量の往復合計である。 式（3）において基本的なオフセット型は $n$ が 0 または は㐿数のとき同時式, $n$ が奇数のとき交互式である。
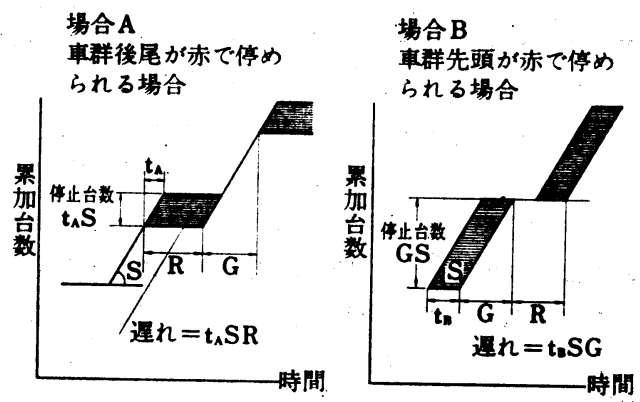

图一7通遗茟のせばまり正と温れ

図一7 から, 通過带のせばまり量が往復合計で $t$ であ るときの 1 サイクル当りリンクの遅れ（往復合計）は,

場合 $\mathrm{A}$ (車群後尾が赤で停められる場合) $t S R$

場合 B (車群先頭が赤で停められる場合) $t S G$ ここに,

\section{$S:$ 飽和流量 \\ $R:$ 赤時間 \\ $G$ : 青時間}

であり，1 サイクル当り交通量は，仮定から往復合計で $2 S G$ であるから, 平均遅れ $d$ は

$$
\begin{array}{rlrl}
d & =\frac{t S R}{2 S G}=\frac{R}{2 G} t & & \text { (場合 A) } \\
& =\frac{t S G}{2 S G}=\frac{1}{2} t & \text { (場合 B) }
\end{array}
$$

となる。仮定から $G=R$ であるから，上式の場合 $\mathrm{A}$ も， $d=1 / 2 \cdot t$ となり, 結局

$$
d=\frac{1}{2} t=\frac{1}{2} \operatorname{Min}|n C-T|
$$

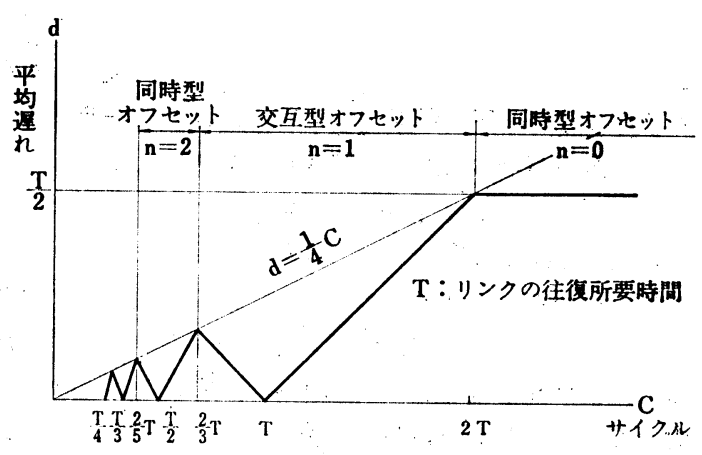

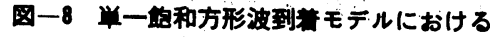
運れとサイクルとの成保

が得られる。

上式から, 平均遅れ $d$ は図一8のよ5に示すことがで きる。

サイクルが $T, T / 2, T / 3, \cdots, T / n$ のときにもっとも 良いオフセットがとれ, 枝村らの拡散のある末飽和単一 方形モデルによる結果 ${ }^{3)}$ と同様である。また $2 T, 2 / 3$. $T, 2 / 5 \cdot T, \cdots$ のときにもっともオフセットがとりにく くなって，遅れが極大值をとる。極大值を結んだ線の勾 配は 1/4 である。これは, 図一2 の完全に飽和した孤立 交差点における遅れの渐近線の勾配 $r / 2=1 / 4(r=1 / 2$ のとき）と一致する。つまり $r=g=1 / 2$ で, 完全に飽和 していれば，もっとも不利なサイクルによる系統制御の 場合の遅れが孤立した交差点の遅れと一致する。

旅行時間当りの遅れがもっとも大きくなるのは $C \geqq$ $2 T$ となるような長いサイクルを用いる域合（あるい は, きわめて近接して信号が配目される場合）であり， 片道 $T / 2$ の走行所有時間に対して遅れも $T / 2$ で, 走行 所有時間と遅れとが等しくなり, 旅行時間は走行所有時 間の 2 倍となる。それ以外の場合, たとえば $C=2 / 3 \cdot T$ では, 片道 $T / 2$ の走行所要時間に対して遅れは $1 / 6 \cdot T$ にすぎず, 遅れは走行所有時間より小さい。

実際の現象では，必ずしも的和していないし 右左折 車, 車群の抬散, 接リンクのオフセット等々の多くの 要因の影整によって，到䫞波形は図一5 に仮定したよら な単純な形ではなく，さまさまに襀雑な形をとり；一般 的なモデル波形として表現することは困難である。定性 的な傾向としては，飽和度が低くなるにつれて，図一8 における遅れの極大值を結ぶ線が $d=1 / 4 \cdot C$ より下に降 りてくることになり，また到着車群の拡散や波形の “く ずれ”が大きくなるほど晕れの栖利值（図一8のモデル ではゼロ）が大きくなる。したがって，これらの影票に よって遅れ一一イクルの関係曲線は，振幅が小さくな り, 遅れがサイクルの増加につれて単洞に增加するとい 5関係に近づく。上流交差点で右左折して到羞する車両 は, 通常の歩行者や現示の条件のもとでは, 直進車群の 
到着より早目に青表示を始める必要性をむたらす（遅れ を減ずるために）ので，見かけ上往復所要時間 $T$ が小 さくなったのと同じ効果をもたらし, 遅れ——サイル の関係曲線が全体に左に圧縮されることになる。

系統制御される場合の停止回数について, 上述の遅れ におけると同じ仮定のもとで計算してみよう。

図一7 から，1 サイクル当り，1 停止線当り停止台数 は, 場合 $\mathrm{A}$ で $t S$, 場合 B で $G S$ であり, 一方図一6 か ら, 往復合計の通過帯のせばまり $t$ 量が $2 R=C$ より

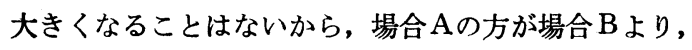
1 サイクル当り往復合計停止台数は小である。

場合 Aとは式（3）において,

$$
n \cdot C-T \leqq 0
$$

となることであるから

$$
T \geqq T-n \cdot C \geqq 0
$$

となるように $n$ を選べば（オフセットを選べば）1 サイ クル当り往復合計停止台数は $t S$ となり,これを 1 サイ クル当り往復合計交通量 $2 G S=C S$ で割れば, 平均停 止回数 $m$ は,

$$
m=\frac{t S}{C S}=\frac{t}{C}=\frac{\min |T-n C|}{C}
$$

となる。

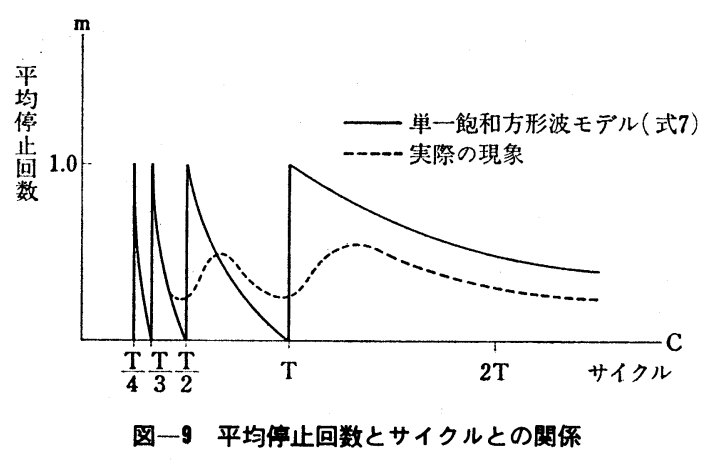

式（7）は図一9の実線で示されるような形となるが， 仮定条件が厳密には成り立たない現実の現象では，場合 B (図一7 参照) の方が場合 Aより停止台数が少ないこ とがあり,その結果図一9の点線で示したような形に近 くなるであろう。

\section{（3）步行者の横断待ち時間}

図一10 のような歩行者用現示の モデルについて横断 待ち時間を考える。

$\alpha_{1}:$ 現示 1 で横断する者の割合

$\alpha_{2}:$ 現示 2 で横断する者の割合

$\alpha_{3}:$ 現示 1 および 2 で各 1 回計 2 回横断する斜め

横断者の割合

$E_{1}$ : 現示 1 における歩行者信号有効点隇時間

$E_{2}:$ 現示 2 における歩行者信号有効点隇時間

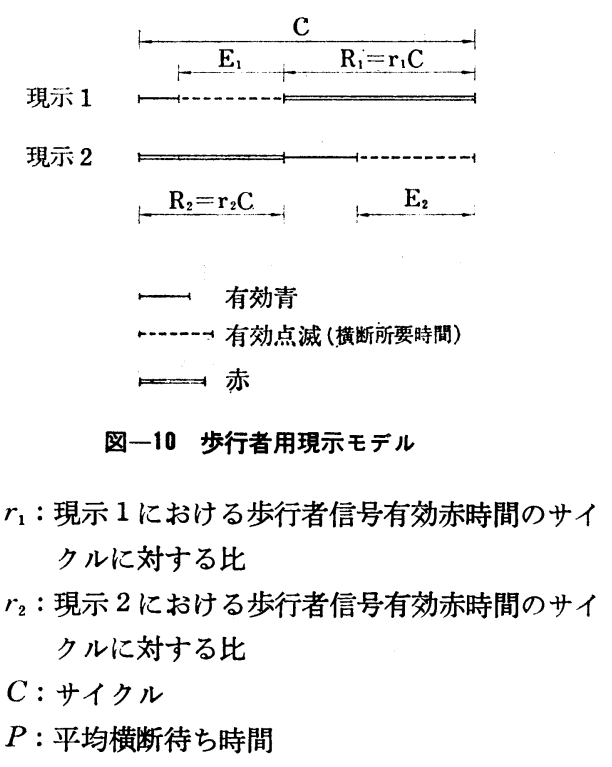

のように信号を定義し, 赤および点滅時間には横断を開 始できないとし，かつ歩行者の到着がランダムであると しょう。

現示 1 で横断する者が横断開始不可時間に到着する確 率は $\left(r_{1} C+E_{1}\right) / C$ であり, この場合の期待待ち時間は $\left(r_{1} C+E_{1}\right) / 2$ でるあから, 平均待ち時間は $\left(r_{1}+C E_{1}\right)^{2} /$ $2 C$ である。現示 2 で横断する者についても, 添字の 1 と 2 とを㯰き換えた対称形で表わされる。2 回横断者に ついては, まず, $E_{1}$ の間に到着した時の第 1 回目横断 までの（現示 2 ) 期待待ち時間が $E_{1} / 2$, 第 1 回目横断が 終ってから第 2 回目横断（現示 1 ) 開始までの待ち時間 が第 2 現示の有効青つまり $C-\left(r_{2} C+E_{2}\right)$ であるから， この場合の期待待ち時間は

$$
\frac{E_{1}}{C}\left(\frac{E_{1}}{2}+C-r_{2} C-E_{2}\right)
$$

である。 $E_{1}$ の間に到着した者についても添字の 1 と 2 とを置き換えることによって表わすことができる。現示 1 の有効青の間に到着する場合については, 到着確率が $\left(C-r_{1} C-E_{1}\right) / C$, 第 2 回目横断の期待待ち時間が $(C-$ $\left.r_{1} C-E_{1}\right) / 2$ であるので, この場合の期待待ち時間は $\left(C-r_{1} C-E_{1}\right)^{2} / 2 C$ となる。現示 2 の有効青の間に到着 する場合についても上と同様添字の 1 と 2 とを置き換え て求められる。

結局, 全横断者の平均横断待ち時間は, 次のように表 わされる。

$$
\begin{aligned}
P & =\alpha_{1} \frac{\left(r_{1} C+E_{1}\right)^{2}}{2 C}+\alpha_{2} \frac{\left(r_{2} C+E_{2}\right)^{2}}{2 C} \\
& +\alpha_{3} \frac{E_{1}}{C} \cdot\left(\frac{E_{1}}{2}+C-r_{2} C-E_{2}\right) \\
& +\alpha_{3} \frac{E_{2}}{C} \cdot\left(\frac{E_{2}}{2}+C-r_{1} C-E_{1}\right)
\end{aligned}
$$




$$
+\alpha_{3} \frac{\left(C-r_{1} C-E_{1}\right)^{2}}{2 C}+\alpha_{3} \frac{\left(C-r_{2} C-E_{2}\right)^{2}}{2 C}
$$

$r_{1}+r_{2}=1.0$ および $\alpha_{1}+\alpha_{2}+\alpha_{3}=1.0$ を考慮して整理 すると

$$
\begin{aligned}
P & =\frac{C}{2}\left\{r_{1}{ }^{2}\left(\alpha_{1}+\alpha_{3}\right)+r_{2}{ }^{2}\left(\alpha_{2}+\alpha_{3}\right)\right\} \\
& +\frac{1}{2 C}\left\{E_{1}{ }^{2}\left(\alpha_{1}+2 \alpha_{3}\right)\right. \\
& \left.+E_{2}{ }^{2}\left(\alpha_{2}+2 \alpha_{3}\right)-4 \alpha_{3} E_{1} E_{2}\right\} \\
& +E_{1}\left(\alpha_{1} r_{1}+2 \alpha_{3} r_{1}-\alpha_{3}\right) \\
& +E_{2}\left(\alpha_{2}+\alpha_{3}-\alpha_{2} r_{1}-2 \alpha_{3} r_{1}\right)
\end{aligned}
$$

と書ける。

さて, $E_{1}$ および $E_{2}$ は歩行者横断所要時間であるか ら交差点の大きさから決まる值であり， $r_{1}$ および $r_{2}$ は スプリットであって, 自動車交通の要請から決まるのが 普通である。

式（8）をサイクルCで微分して最適サイクル $C_{\mathrm{op}}$ を 求めると,

$$
C_{\mathrm{op}}=\sqrt{\frac{E_{1}{ }^{2}\left(\alpha_{1}+2 \alpha_{3}\right)+E_{2}^{2}\left(\alpha_{2}+2 \alpha_{3}\right)-4 \alpha_{3} E_{1} E_{2}}{\left(\alpha_{1}+\alpha_{3}\right) r_{1}{ }^{2}+\left(\alpha_{2}+\alpha_{3}\right) r_{2}{ }^{2}}}
$$

となる。

いま仮に

$$
\begin{aligned}
r_{1} & =0.4 & & r_{2}=0.6 \\
\alpha_{1} & =0.3 & & \alpha_{2}=0.4 \\
E_{1} & =10 \mathrm{sec} & E_{2} & =20 \mathrm{sec}
\end{aligned} \quad \alpha_{3}=0.3
$$

とおいて平均横断待ち時間とサイクルとの関係を計算し てみると図一11のようになる。最適サイクル $C_{\mathrm{op}}$ は， $20.6 \mathrm{sec}$ であって, サイクルの許容範囲より小さな值と なる。また，極端な場合として, $E_{1}=20 \mathrm{sec}, E_{2}=30 \mathrm{sec}$, $\alpha_{1}=0.4, \alpha_{2}=0.6, \alpha_{3}=0, r_{1}=0.6, r_{2}=0.4$ として計算 しても， $C_{\mathrm{op}}=54 \mathrm{sec}$ に過ぎない（このとき最小サイク ルは $50 \mathrm{sec}$ )。このことから, 通常の交差点における横 断歩行者にとっての遅れ最小サイクルは, 車両用常用サ イクルに比してかなり小さい值であるということがで き,一般には, サイクルを短縮すれば歩行者横断待ちも

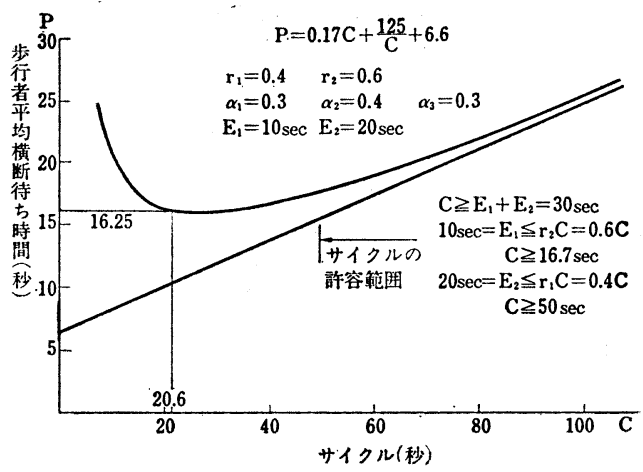

図一11歩行者平均栱断待ち時間とサイクルとの 関保数值計策例
小さくすることができる。

\section{3. 実 験 值}

図一12 に示すような 交通信号制御実験 システムにお いて, 70 秒から 120 秒まで, 5 秒間隔に 11 通りにサ イクルを変化させることによって，サイクルと遅れおよ び停止との関係を実験的に求めた。スプリット（96) は 固定し, オフセットは, 微係数法による追従制御“をを行 って，遅れ最小になるように制御したので，常に動いて おり,一定値ではない。遅れおよび停止台数は, 各停止
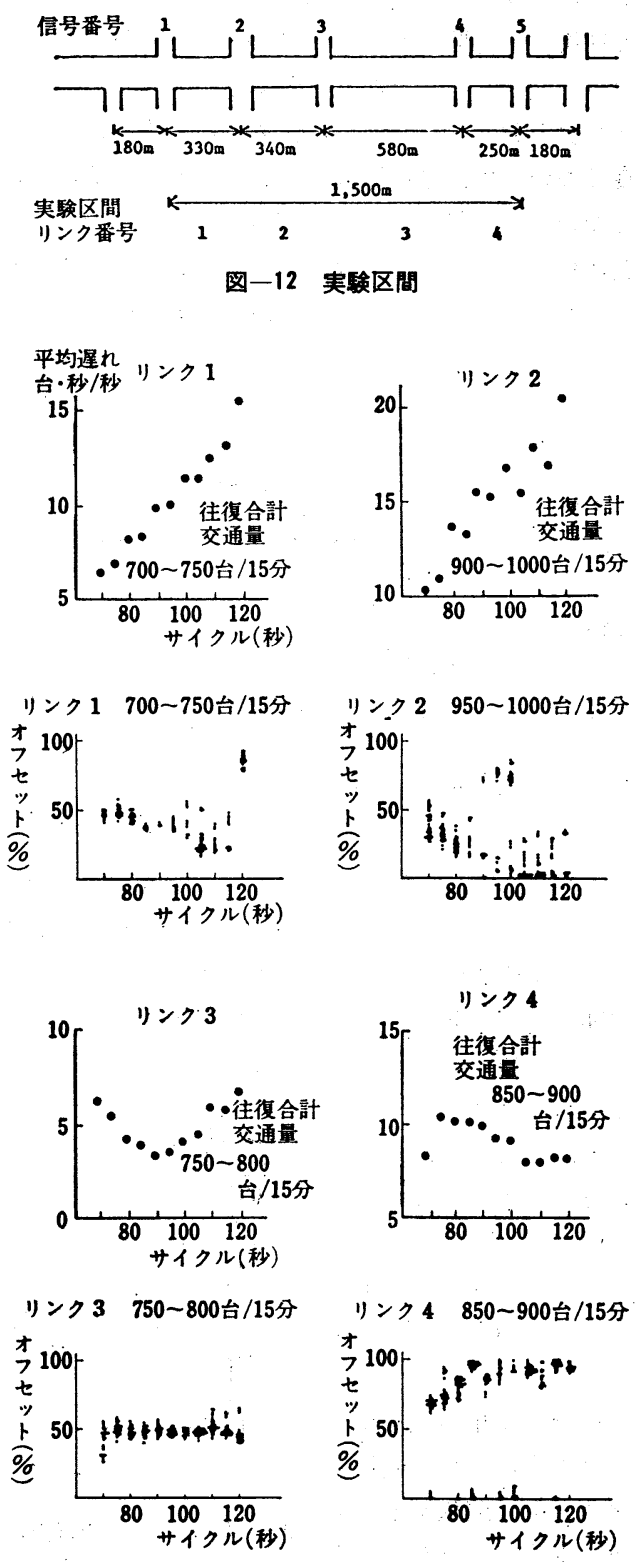

図一13 リンク別迤れとサイクルとの閔保（実験值） 
線ごとに，停止線上流約 $150 \mathrm{~m}$ の位㯰にある 車両感知 器情報と, オフライン実測から求めた飽和流量とから, オンラインで計算した。

\section{(1) 革れ}

図一13 は各リンクの遅れとサイクルとの関係を示す ものである。各点は数個の 15 分実測值の平均值であ る。リンク 3 は約 92 秒で極小値, リンク 4 は約 80 秒 で極大值をとっている。リンク長はそれぞれ $580 \mathrm{~m}$ お よび $250 \mathrm{~m}$ であり，右左折車はあまり多くないので， 走行速度を $12.5 \mathrm{~m} / \mathrm{sec}(45 \mathrm{~km} / \mathrm{hr})$ と仮定すると, リン ク 3 では往復走行時間 $T=92.8 \mathrm{sec}$ で極小值, リンク 4 では往復走行時間 $\times 2=2 T=80 \mathrm{sec}$ で極大值をとること になり,図一8の形とほぼ一致する。

リンク 1 およびリンク 2 は, 右左折が多く, 沿道条件 も良くないので, 走行速度はリンク 1 および 3 ほどには 高くない。図一13 では 70 秒から 120 秒のサイクルの 範囲に極大值も極小值も現われていないので往復走行時 間 $T$ の推定ができないが，少なくとも図から $T \leqq 70$ $\mathrm{sec}, 2 T \geqq 120 \mathrm{sec}$ であろう。

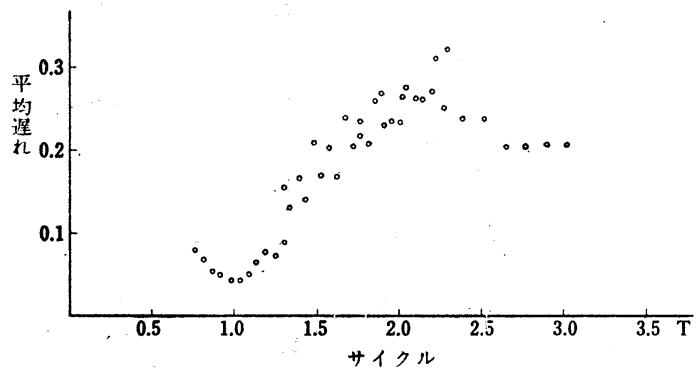

図一14 $T$ で正規化したサイクルと平均遲れ との閶係（実験値）

図一14 は, 実験結果を図一8のモデル計算と照合し やすくするために, 図一13 のデータをサイクルと平均 遅れとの関係に直し, かつ, 両軸ともリンク往復走行所 要時間 $T$ で正規化して示したものである。単純モデル による計算值と似た形をしているのがわかる。リンク 1 およびリンク 2 の $T$ は, い ずれも 60 秒と仮定した。 これはリンク 1 では $11 \mathrm{~m} /$ $\sec (39.6 \mathrm{~km} / \mathrm{hr})$, リンク 2 では $11.3 \mathrm{~m} / \mathrm{sec}(40.8 \mathrm{~km} /$ hr）の走行速度に相当す る。

図一15 は, 単純に 4 つの リンクを合計した総遅れと サイクルとの関係を示すも ので, 多少の波はあるが全 体としてはサイクルの増加

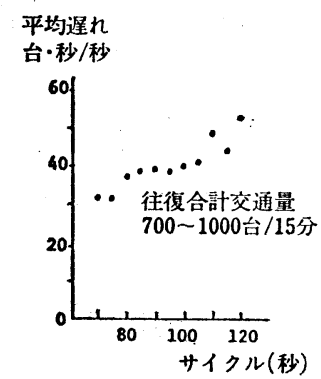

図-154リンク合計痋れと サイクルとの開係 (実験値)
につれて総遅れもほぼ比例的に増加するという傾向を持 つ。

\section{（2）停止}

実験が遅れを最小にするようなオフセット制御のもと で行われたので，停止回数に関しては必ずしも最適オフ セットをとっていないが，近似的な現象の観察にはたえ るであろう。

図一16 は, 各リンクの停止台数とサイクルとの関係 を示すものであり，図一17 は，図一9 と対比しやすいよ うにサイクルを $T$ の単位で表わして示したものである。 $T$ には図一14におけるものと同じ值を用いた。図一17 は, 図一9 とかなり似た形をしているが, リンク 1 およ びリンク 2 は, 右左折車が多いために平均停止回数はリ ンク 3 およびリンク 4 より全般にかなり多い。
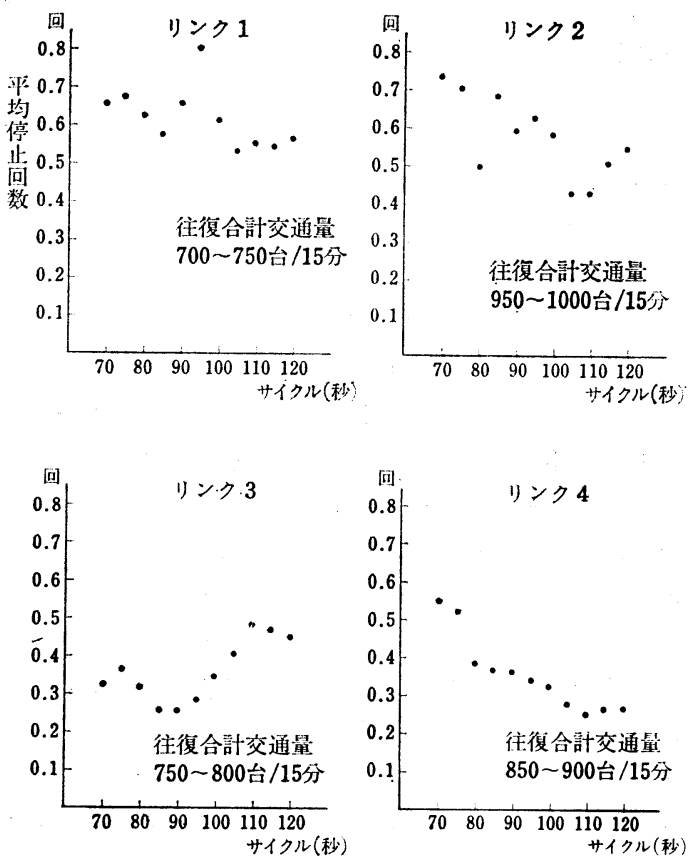

図一16 リンク別平均停止回数とサイクルとの関係 （実験值）

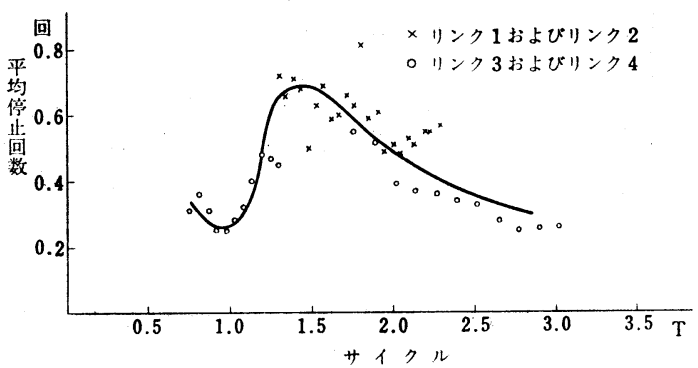

图一17Tで正規化したサイクルと平均侣止回数 との関保 (実験值) 


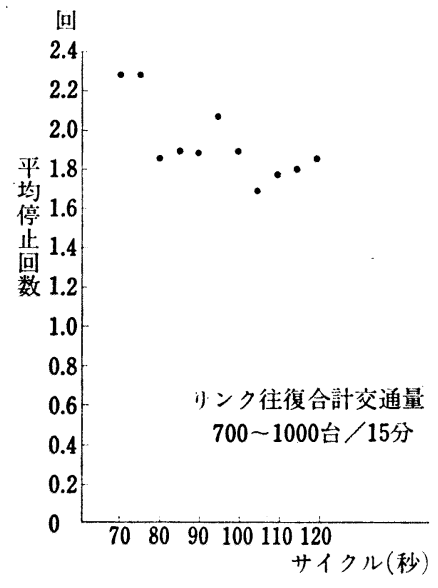

図一184リンク合計平均停止回数とサイクル との関係 (実験値)

図一18 は 4つのリンクを単純に合計した 総停止台数 とサイクルとの関係を示すものである。サイクルの増加 につれてやや停止台数が減少する傾向が認められる。

\section{4. 系統制御における遅れおよび停止のサイク ルに関する微係数とサイクルのオンライン 最適化実験}

\section{（1）遅れのサイクルに関する微係数}

一般に, サイクルの変化は 2 つ面で系統リンクの遅 れに影響する。ひとつはオフセット(秒)の変化の効果で あり,も5ひとつは, 到着波形がサイクルと相似的に変 化した場合には 1 サイクル当り遅れがサイクルの 2 乗に 比例するという効果である。まず, 第 1 の効果について 考えてみよう。

任意の系統リンクの相対オフセットに関する遅れある いは停止の微係数をオンライン計測することができるこ とはすでに示したところである゙)。この計測は，停止線 の飽和流量を一定と推定できれば，停止線の上流 100〜 $150 \mathrm{~m}$ の位置に設けた車両感知器 1 基（停止線当り）で 可能である。

両端に信号停止線 $A$ おび $B$ を持つひとつのリンクを 考えよう。Bの青の始まりからAの青の始まりまでの時 間差をこのリンクの相対オフセットと定義しよう。 $h_{A}$ および $h_{B}$ を各停止線での 1 サイクル当り遅れの相対オ フセットに関する微係数とすると, $h_{A}+h_{B}$ は, このリ ンクの1サイクル当り遅れの相対オフセットに関する微 係数である。オフセットのオンライン最適化は, $\mid h_{A}+$ $h_{B} \mid$ がある闇值をこえたときに, 遅れを減少させる方向 に相対オフセットをシフトすることによって行うことが できる。
いま $h_{A}-h_{B}$ をとって，その意味を考えてみよう。 $h_{A}>0$ は， $A$ の青が $B$ との相対において現在より 1 秒だけ早く始まれば $A$ での 1 サイクル当り遅れが $h_{A}$ だけ減少することを意味する。同様に $h_{B}<0$ は $B$ の青 が $A$ との相対において現在より 1 秒だけ早く始まれば $B$ での 1 サイクル当り遅れが $h_{B}$ だけ減少することを意 味する。したがって，もし $A$ にも $B$ にも互いに相手との 相対において 1 秒ずつ早く青を与えることができれば， このリンクの 1 サイクル当り遅れは $h_{A}-h_{B}$ だけ減少 することになる。当然のことながらオフセットをいかに 変化させてもそのようにすることはできないが，もしサ イクルを 2 秒短縮すればそれは可能となる。

このことから, $h_{A}-h_{B}$ は, サイクルの変化に伴って オフセットが改善されることによる 1 サイクル当り遅れ の減少の目安となる量であることが知られる。そこで, $1 / 2 \cdot\left(h_{A}-h_{B}\right)$ を, “リンクの遅れのサイクルに関する見 かけの微係数’と名づけることにしよう。

次に, 第 2 の効果, 寸なわち, サイクルと遅れとの一 般的関係として, もし到着波形が相似で, ・オフセット （sec）が同じだとすれば, 1 サイクル当り遅れはサイク ルの 2 乗に比例するという事実に注意すれば次のような 式を置くことができる。

$$
\left.\begin{array}{l}
W(C+\Delta C)=\{W(C)+h(C) \cdot \Delta C\}\left(\frac{C+\Delta C}{C}\right)^{2} \\
h(C)=\frac{1}{2}\left\{h_{A}(C)-h_{B}(C)\right\}
\end{array}\right\}
$$

ここに,

$$
C: \text { サイクル }
$$

$W(C)$ : リンクの1サイクル当り遅れ

$h(C)$ : リンクの 1 サイクル当り遅れのサイクル に関する見かけの微係数

$$
w(C)=\frac{W(C)}{C}
$$

ここに, $w(C)$ : リンクの単位時間当り遅れとすれば,

$$
w(C+\Delta C)-w(C)=\frac{W(C+\Delta C)}{C+\Delta C}-\frac{W(C)}{C}
$$

となり, 式 (9), (10) および (11) から,

$$
\begin{aligned}
& \frac{W(C+\Delta C)}{C+\Delta C}=\{W(C)+h(C) \cdot \Delta C\} \frac{C+\Delta C}{C^{2}} \\
&=\frac{W(C)}{C}+W(C) \frac{\Delta C}{C^{2}} \\
&+h(C) \cdot \Delta C \frac{C+\Delta C}{C^{2}} \\
& \frac{W(C+\Delta C)}{C+\Delta C}-\frac{W(C)}{C}=\frac{W(C)}{C^{2}} \cdot \Delta C \\
&+h(C) \cdot \Delta C \frac{C+\Delta C}{C^{2}}
\end{aligned}
$$




$$
\begin{gathered}
\frac{w(C+\Delta C)-w(C)}{\Delta C}=\frac{W(C)}{C^{2}}+h(C) \frac{C+\Delta C}{C^{2}} \\
\begin{aligned}
\frac{d}{d C} w(C) & =\lim _{\Delta C \rightarrow 0}\left\{\frac{w(C+\Delta C)-w(C)}{\Delta C}\right\} \\
& =\frac{W(C)}{C^{2}}+\frac{h(C)}{C}
\end{aligned}
\end{gathered}
$$

または

$$
=\frac{w(C)+h(C)}{C}
$$

として, 単位時間当り遅れのサイクルに関する微係数を 表わすことができる。式 (12) における1 サイクル当り 遅れ $W(C)$ は, $h(C)$ を計測するのに必要な車両感知 器でオンライン計測が可能である。

\section{（2） 停止台数のサイクルに関する微係数}

同様な考察によって，単位時間当り停止台数のサイク ルに関する微係数を導くことができる。

$$
\begin{aligned}
& S(C+\Delta C)=\{S(C)+k(C) \cdot \Delta C\} \frac{C+\Delta C}{C} \\
& h(C)=\frac{1}{2}\left\{k_{A}(C)-k_{B}(C)\right\} \\
& s(C)=\frac{S(C)}{C} \\
& \frac{S(C+\Delta C)}{C+\Delta C}=\frac{S(C)}{C}+\frac{k(C) \cdot \Delta C}{C} \\
& \frac{s(C+\Delta C)-s(C)}{\Delta C}=\frac{k(C)}{C} \\
& \frac{d}{d C} s(C)=\frac{k(C)}{C} \\
& こ こ に,
\end{aligned}
$$

$S(C)$ ：1 サイクル当りリンクの停止台数

$k_{A}(C)$ および $k_{B}(C)$ : 停止線 $A$ および $B$ におけ る1サイクル当り停止台数のオフセットに 関する微係数

\section{（3） サイクルのオンライン最適化実験}

上述の微係数を用いて, サイクルのオンライン最適化 制御がもし適切に機能すれば, 交通量, 右左折, リンク 長, 速度等々のすべてを考慮したサイクルの自動的な最 適化が可能となって，きわめて好都合である。そこで， 図一12 に示される実験 システムにおいて, 遅れのサイ クルに関する微係数を用いてサイクルのオンライン最適 化実験を行った。スプリット(\%)は固定し，オフセット はオンライン追従制御によって常時最適化するよう動か した。図一19 はリンク 3 のみに適用した場合, 図一20 は 4つのリンク合計について, 適用した場合の結果であ る。リンク 3 のみの場合には, 明らかに図一12 から知 られる最適サイクルの 90 秒付近に収束する。 4 リンク
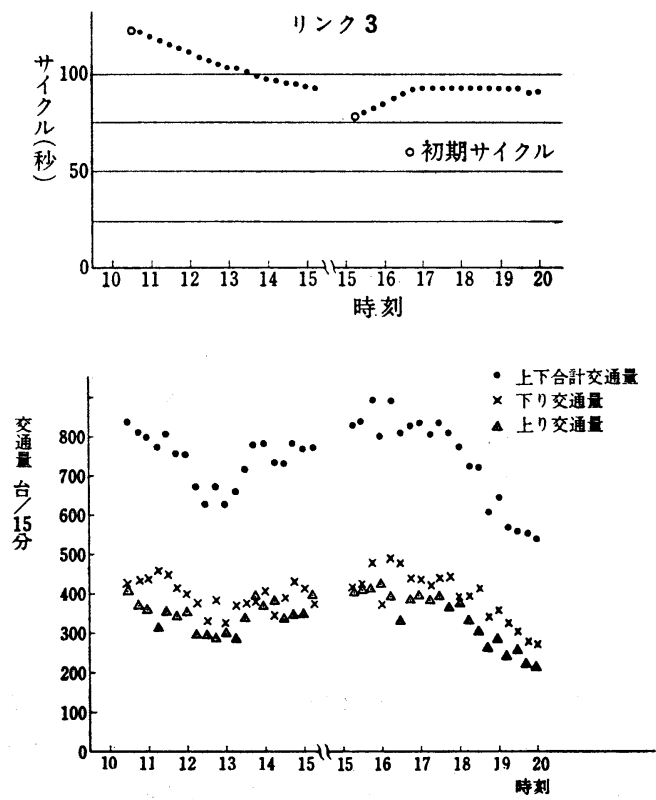

図一19サイクル最適化実験結果（リンク３）

合計の場合には, 110 秒から出発す ると 95 秒付近で 収束し, 80 秒から 始めると 75 秒に 近づく。これは 4 つのリンク合計の 遅れ——サイクル の関係が単調では なく, 図一13 から

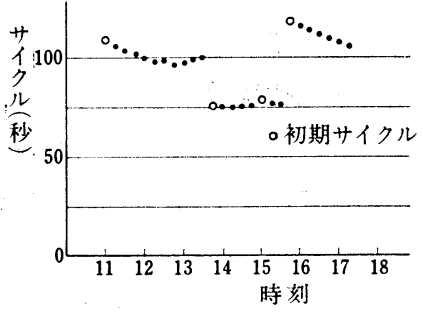

図一20 サイクルの最適化実験結果

(リンク $1 \sim 4$ 合計) もうかがわれるように，95 秒付近および 75 秒付近に局 地的な極小値があるためと思われる。交通量は，昼食時 と夕刻とにおいて減少しているが, 交通量の減少は走行 速度の増大 $\rightarrow$ 往復所要時間 $T$ の減少 $\rightarrow$ 最適サイクルの 減少といら効果を持ち, 図一19 の $19: 30$ 以降および 図一20の 12:30 13:00 付近においてその影響がわ ずかに認められる。

\section{5. 結 論}

系統制御における最適サイクルは，主として信号間隔 と系統速度とによって定まる。系統速度を $11 \mathrm{~m} / \mathrm{sec}$ (約 $40 \mathrm{~km} / \mathrm{hr}$ ) と仮定すると, 通常都市内で用いられる 90 $\sec$ 程度のサイクルにおいては，信号間隔約 $250 \mathrm{~m}$ から $500 \mathrm{~m}$ の間のリンクでは遅れとサイクルとの関係は図一 8 に示した $T$ と $2 T$ との間にあり, サイクルの $1 \%$ の 短縮によって遅れが $1 \%$ 以上減少するという範囲にあ る。都市内の系統化された信号の大部分はこの範井の間 
隔にあるから，サイクルの短縮は遅れの減少に大きく寄 与寸ることがわかる。70 秒程度のサイクルにおいても なお, 信号間隔約 190 390 m のリンクではサイクルが $T$ と $2 T$ の間にくる。

横断歩行者の待ち時間は, かなり特殊な場合でも通常 用いることのできるサイクルの範囲より短いサイクルで 最小となるので, 普通はサイクルを短縮することによっ て歩行者の横断待ちもまた短くなると考えることができ る。

したがって, 都市内道路網系統制御におけるサイクル 制御の政策は，できるだけ短いサイクルを用いることで あるということができ, そのためには飽和度の高い交差 点において, 無䭾青を出さない有効なスプリット制御が できなりればならない。系統制御におけるスプリット制 御は, この点で孤立した交差点の場合とは異なった意味 をもち,さらに重要性が高い。

効外部などにおいて, 信号間隔が長く, 走行速度も高 くて, 多くのリンクの往復所要時間 $T$ が常用のサイク ルあるいはその整数倍の範囲に入るような場合には, 最 短サイクルではない最適サイクルが存在しらることは明 らかである。このような場合のサイクル最適化ももちろ
ん重要で興味深い問題であり,これについては別の機会 に報告したいと考えている。

遅れのサイクルに関する微係数を用いたオンライン最 適化制御は，理論と実験結果との合致はきわめて良い。 しかし実用的にはすべてのリンクに車両感知器を設けな ければならず，また局地極小值に陥ち込むことがあると いう点に問題がある。いずれにせよ，できるだけ短いサ

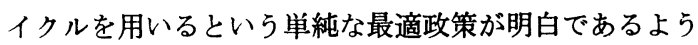
な場合には,このようなオンライン最適化はあまり実用 的な意味を持たないといえる。

\section{考文献}

1) Webster, F.V. : Delays at Traffic Signals FixedTime Signals, Road Research Laboratory, Research Note 2374 .

2）交通工学研究会：広域交通信号制御の研究報告書, 昭和 41 年 3 月.

3）枝村・久井：系統式信号制御パラメーターに関する一考 察, 交通工学, Vol. 5, No. 5, 昭和 45 年 9 月.

4）越：広域交通信号制御における信号オフセットのプログ ラム形成のひとつの方法, 生産研究 20,3 , 昭和 43 年 3 月.

5) 越: Optimization of Cycle Time for Computerized Traffic Signal Systems, 生産研究 26, 10, 昭和 49 年 10 月.

(1974.12.19 - 受付) 